PERM JOURNAL OF PETROLEUM AND MINING ENGINEERING ВЕСТНИК ПНИПУ. ГЕОЛОГИЯ. НЕФТЕГАЗОВОЕ И ГОРНОЕ ДЕЛО

ISSN 2224-9923

Volume / Tом 16 №4 2017

http://vestnik-pstu.ru/geo/

УДК 622.454.2:622.81

Article / Статья

(C) PNRPU / ПНИПУ, 2017

\title{
ENSURING THE SAFETY AND ENERGY EFFICIENCY OF VENTILATION OF SHAFTS AND MINES THAT USE THE AIR RECYCLING SYSTEM
}

\section{Aleksandr V. Nikolaev, Nikolaj I. Alymenko', Mikhail Chekhlar², Yurai Janocko², Daniil N. Alymenko ${ }^{3}$, Viktor A. Nikolaev}

Perm National Research Polytechnic University (29 Komsomolskiy av., Perm, Russian Federation, 614990)

${ }^{1}$ Mining Institute of the Ural Branch of the Russian Academy of Sciences (78 Sibirskaya st., Building A, Perm, 614007, Russian Federation)

${ }^{2}$ Technical University of Kosice (9 Letna st., Kosice, 04200, Slovak Republic)

${ }^{3}$ Ural Research and Development Institute of halurgy JSC (94 Sibirskaya st., Perm, 614002, Russian Federation)

\section{ОБЕСПЕЧЕНИЕ БЕЗОПАСНОСТИ И ЭНЕРГОЭФФЕКТИВНОСТИ ПРИ ПРОВЕТРИВАНИИ ШАХТ И РУДНИКОВ, ИСПОЛЬЗУЮЩИХ СИСТЕМУ РЕЦИРКУЛЯЦИИ ВОЗДУХА}

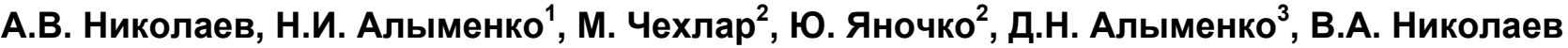

Пермский национальный исследовательский политехнический университет (614990, Россия, г. Пермь, Комсомольский пр., 29) ${ }^{1}$ Горный институт Уральского отделения Российской академии наук (614007, Россия, г. Пермь, ул. Сибирская, 78а)

${ }^{2}$ Технический университет Кошице (04200, Словакия, г. Кошице, ул. Летна, 9)

${ }^{3} \mathrm{AO}$ «ВНИИ Галургии» (614002, Россия, г. Пермь, ул. Сибирская, 94)

Received / Получена: 07.08.2017. Accepted / Принята: 12.10.2017. Published / Опубликована: 01.12.2017

Key words:

recirculation, main ventilation unit, air stream reverse, mining safety, energy saving.
The paper describes the possible failures in the automation ventilation system with partial return use of upcast air from a shaft or mine (during recirculation). Existing ventilation systems use recirculation in the main ventilation mining, through which air is delivered from an underground mining enterprise. It is proposed to install automatic ventilation doors (AVD). They allow to change the aerodynamic resistance of the mine, i.e. control flow rate of air discharged from a mine (shaft). If an AVD is damaged the dangerous case could arise even in a normal ventilation mode due to the fact that mentioned negative control means can block the main path of air movement. In this case air from the air-supplying barrels is directed to the ventilation barrel through the recirculation loop bypassing the mining sites dedicated for ventilation. At the time of accident, when the main fan unit (MFU) is reversed, such a failure makes the situation even more dangerous due to the unpredictable path of flue gases.

In the method described it is proposed to install the AVD in the mines of the main directions and close them only during the period of the MFU reverse. When the closing AVD and forced draft fan of the main air heater work together and discharge air in the reverse mode, the time dedicated for switching of the main heater to the reverse mode is reduced. After the gradual opening of the AVD in the shaft (mine) a reversible mode of ventilation is installed.

The method proposed allows energy and resource savings for ventilation and air preparation both in normal and emergency modes while meeting the safety requirements for mining operations.
Ключевые слова: рециркуляция, главная вентиляторная установка, реверс струи воздуха, безопасность ведения горных работ, энергосбережение.
Приводится описание возможных отказов в системе автоматизации проветривания при частичном повторном использовании исходящего из шахты или рудника воздуха (при рециркуляции). В существующих системах проветривания, использующих рещиркуляцию в главных вентиляционных выработках, по которым осушествляется вылача воздуха из подземного горнодобывающего предприятия, предлагается устанавливать автоматические вентиляционные двери (АВД). С их помощью обеспечивается изменение аэродинамического сопротивления рудника, т.е. регулируется расход выдаваемого из рудника (шахты) воздуха. При выходе из строя АВД даже в нормальном режиме проветривания может возникнуть опасная ситуация, связанная с тем, что указанные средства отрицательного регулирования могут преградить основной путь движения воздуха. В этом случае через рециркуляционный контур воздух из воздухоподающих стволов направится в вентиляционный ствол, минуя горные выработки, прелназначенные для проветривания. В момент возникновения аварии, при реверсе главной вентиляторной установки (ГВУ), подобный отказ делает ситуацию еще более опасной ввиду непредсказуемости пути движения дымовых газов.

В описанном в работе способе предлагается АВД устанавливать в выработках главных направлений и закрывать их только в период осуществления реверса ГВУ. При совместной работе закрывающихся АВД и нагнетательных вентиляторов шахтной калориферной установки, осуществляющих в этот момент выдачу воздуха в реверсивном режиме, снижается время на реализацию процесса перевода ГВУ в реверсивный режим. После постепенного открытия АВД в шахте (руднике) будет установлен реверсивный режим проветривания.

В предлагаемом способе обеспечивается энерго- и ресурсосбережение при проветривании и воздухоподготовке как в нормальном, так и в аварийном режимах при соблюдении требований безопасности ведения горных работ.

Aleksandr V. Nikolaev (Author ID in Scopus: 7202396660) - PhD in Engineering, Associate Professor at the Department of Mine Electromechanics (mob. tel.: +007 908 24140 19, e-mail: nikolaev0811@mail.ru). The contact person for correspondence.

Nikolaj I. Alymenko (Author ID in Scopus: 54895153400) - Doctor of Engineering, Professor, Chief Research Fellow at the Laboratory of Geotechnological Processes and Mine Gas Dynamics (mob. tel.: +007912 78980 86, e-mail: nik.alymenko@yandex.ru).

Mikhail Chekhlar - Doctor of Engineering, Professor, Dean of the Faculty of Mining, Ecology, Management and Geotechnologies (mob. tel.: +421 055 602 31 36, e-mail: michal.cehlar@tuke.sk). Yurai Janocko - Doctor of Engineering, Professor, Deputy Dean for Research, Sciences and Postgraduate Education at the Faculty of Mining, Ecology, Management and Geotechnologies (mob. tel.: +4210915865 144, e-mail: juraj.janocko@tuke.sk)

Daniil N. Alymenko - PhD in Engineering, Director for Science (tel.: +007342 21668 17, e-mail: mail@gallurgy.ru)

Viktor A. Nikolaev - Senior Lecturer at the Department of Mine Electromechanics (mob. tel.: +007 90824140 19, e-mail: nikolaev.va.pstu@mail.ru)

Николаев Александр Викторович - кандидат технических наук, доцент кафедры горной электромеханики (моб. тел.: +007 9082414019 , е-таil:

nikolaev0811@mail.ru). Контактне лицо для переписки. Алыменко Николай Иванович - доктор технических наук, профессор, глав

Чехлар Мики (моб. тел.: +007 91278980 86, e-mail: nik.alymenko@yandex.ru). Яночко Юрай - доктор технических наук, профессор, заместитель декана по исследованиям, науке и послевузовскому образованию факультета горного дела, экологии, менеджмента и геотехнологий (моб. тел.: +421 0915865 144, e-mail: juraj.janocko@tuke.sk).

экологии, менеджмента и геотехнологий (моб. тел.: +421 0915865 144, e-mail: juraj.janocko@tuke.sk).

Николаев Виктор Александрович - старший преподаватель кафедры горной электромеханики (моб. тел.: +007 90687722 28, e-mail: nikolaev.va.pstu@mail.ru). 


\section{Introduction}

The challegne of energy conservation becomes more and more urgent over the years in the Russian Federation and world. That is the cause why equipment, production methods, manufacturing techniques and other measures are modifyied in all the industries.

For the mining industry, which is energy and resource-intensive, that challenge is also urgent. In order to solve it means that could increase the energy efficiency of production are trying to be found. Due to the fact that from 30 to $50 \%$ of all electricity consumed by mining enterprise is used for ventilation [1], precisely that area is needed to be improved in terms of energy efficiency.

It was suggested in the 30 's of the last century in mining enterprises to partially reuse (recirculate) the air when a certain part of it coming from the shaft (mine) was again sent to a fresh stream [2-11]. In this case, electric consumption for the operation of the main fan unit (MFU) is decreased significantly. It also allows to reduce the cost of energy resources during air preparation in the cold season and get rid of the need to use air conditioning system in the warm season in shallow mines and shaft, which is energy-intensive [12-14].

Considering the fact that today all the processes in production tend to be converted to automatic or semi-automatic (automated) modes, it was proposed in one of them [14-18] to control the ventilation process with use of a recirculation loop.

In order to ensure energy savings in the ventilation of shafts and mines in which the recirculation system is used, it is necessary to automate the process of controlling air distribution and monitor the operation of all elements of the system. However, before development of the control algorithm itself, it is necessary to consider all factors that, in addition to energy saving, will affect mining safety which is the most important.

\section{Ventilation of the shaft (mine) using a recirculation system at normal and emergency conditions}

At the normal ventilation mode, when using a system for partial air reuse, it is necessary to determine the recirculation ratio, which according to $[19,20]$ looks like

$$
K_{\mathrm{rec}}=\frac{Q_{\mathrm{rec}}}{\left(Q_{\mathrm{s}}+Q_{\mathrm{rec}}\right)}
$$

where $Q_{\text {rec }}$ - volume of recirculated air, $\mathrm{m}^{3} / \mathrm{s} ; Q_{\mathrm{s}}-$ the total volume of air entering the shaft (mine), $\mathrm{m}^{3} / \mathrm{s}$.

In order to maintain the required maximum permissible recirculation ratio $K_{\mathrm{rec}}^{\max }$ it is proposed in [15] to control the speed of rotation of the impeller of the recirculating fan $\left(\omega_{\text {rec }}\right)$, depending on the current value of the recirculation ratio depending on the current value of the recirculation ratio $\left(K_{\text {rec }}\right)$ :

$$
\frac{d \omega_{\mathrm{rec}}}{d t}=a\left(K_{\mathrm{rec}}^{\mathrm{max}}-K_{\mathrm{rec}}(t)\right)+b \int\left(K_{\mathrm{rec}}^{\mathrm{max}}-K_{\mathrm{rec}}(t)\right) d t
$$

where $a$ and $b$ are weight coefficients of equation.

In order to maintain the required recirculation parameters it is also proposed in [15] to install automatic mine ventilation doors (AVD) in the main ventilation shafts.

From the point of view of ensuring energy saving, the effectiveness of the method of ventillation is obvious. However, in case of abnormal situation, certain problems may arise in the application of this method. For example, according to [21] it is necessary to reverse (change direction) the air stream in the shaft (mine) within 10 minutes in case of fire in underground mines. In this case, during the time mentioned the air continues to move in the direction previously established. After that, the MVU is switched to the reverse mode, and the air begins to flow through the ventilation shaft to the pit (mine).

Case 1. When the stream was reversed in a pit (mine) operated by a suction method with partial air reuse, the AVD that are in the recirculation loop of "horizon" have failed and remained in the open position (Fig. la).

In the case, before turning on the MVU into reversible mode, even with off recirculation fan, some of the air coming from the mine will be supplied to a fresh stream. Due to the fact that after the outbreak of fire in the outgoing air flue gases can be in dangerous concentrations, a similar situation can become dangerous for life and health of miners in the pit (mine).

As was mentioned, switching of the MVU to reverse mode should be carried out in no more than 10 minutes, i.e. the case of interest should not cause a significant danger. However, it was 
established in $[22,23]$ that after reversal of MVU, the direction of air movement only changes in the ventilation trunk and in the MVUs. That is caused by the fact that goaf spaces at this time begin to play the role of sources of traction and in the airsupplying trunks and excavations of the main directions, the air continues to move in the same direction that was established earlier (see Fig. 1b).
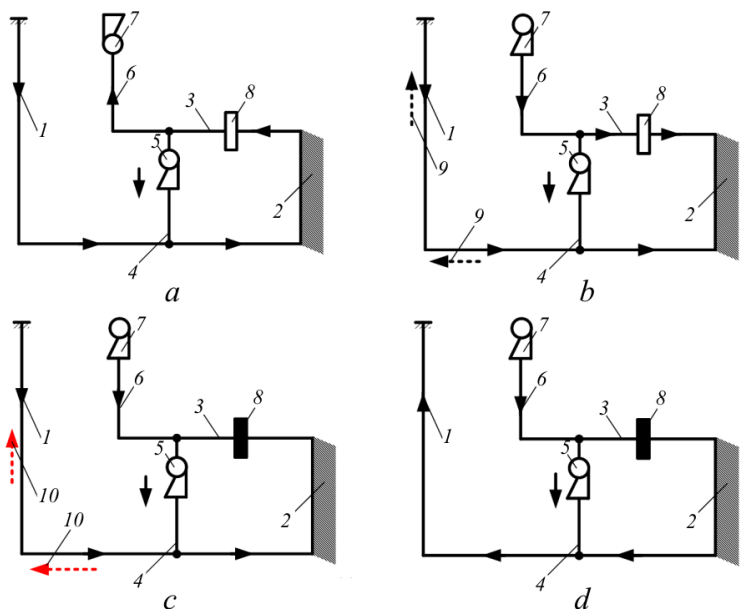

Fig. 1. Simplified scheme of mine ventilation using the recirculation system wedging the AVD in open $(a, b)$ and closed $(c, d)$ position: 1 - air supplying trunk; 2 - goaf space and production sites; 3 - main ventilation excavations; 4 - recirculation circuit; 5 - recirculation fan; 6 - ventilating barrel; 7 - MVU; 8 - AVD; 9 - required direction of air movement at reverse mode; 10 - direction of flue gas movement

It is clear that if the AVD is wedged in the recirculation loop in the open position, air from the vent will flow into the exhausted space. Such a situation will contribute to an increase in the time for transferring the airing regime to the reversible regime. At this time, the flue gases will not not leave the underground part of the mining enterprise, and as a result of the continuation of the combustion process, they will accumulate in it [24-29].

A similar situation arises in the normal operating mode of the AVD. When trying to close them at a certain angle, the aerodynamic resistance of the main ventilation excavations increases, which will become an obstacle during the work of MVU. Considering that proposed automation system of the ventilation protection does not protect miners from the occurrence of an abnormal case (fire in underground mine workings) in case of wedging of AED.

Case 2. AVD was damaged in closed position when the stream was reversed in the pit (mine) operating by a suction ventilation method with partial air reuse.

As it was stated earlier that wedging of the AVD in the open position, in fact, is a regular mode of operation and does not interfere with the regime of reversing the stream either. The more dangerous situation arises when the AVD is wedged in the closed position. In this case, the air from the ventilation shaft through the recirculation loop will directly flow into the excavations of the main directions and air supplying shaft (see Fig. 1c). At the same time, before changing the direction of air movement in the air supplying trunks due to the backfilling of the goaf space, the focus of the fire in the mine excavations will be supplied with fresh air. When changing the direction of the air stream in the air supply shafts, the flue gases will go through them to the surface (see Fig. 1c), i.e. fill all the mining excavations where people are at that moment.

An even more dangerous case arises when a fire is formed in or near the barrel of the airsupplying trunk. In such case there will be no chance that mining excavations, protected from inflow of flue gas and carrying no miners, remain.

The case when AVD are wedged in a closed position is also dangerous in the normal ventilation mode, since the access to the main and sometimes only one ventilation source (MVU) will be blocked, which supplies air to the pit (mine). At the same time, air from the air supply shafts through the recirculation circuit will start to flow directly into the ventilation shaft, bypassing mining areas with miners.

When the MVU is reversesed through the recirculation loop, air goes to the air-supplying trunk, violating the air distribution in the excavations (see Fig. 1d). After the release of air out of the exhausted space, it will be impossible to direct fresh air into the excavations since in any case having it turned on, the MVU in normal (nonreversible) mode will follow the shortest path from the air supplying trunks to the ventilation path through the recirculation loop or in the opposite direction.

The cases considered indicate that when using the AVD in the main ventilation excavation and air recirculation system, it is possible to reduce the energy costs of ventilation by reducing the MVU productivity and total volume of air entering the mine (air preparation). In the event of emergency, 
such as a fire, that ventilation system will in some cases create dangerous conditions for the life and health of miners.

\section{Method proposed for automation of ventilation using the recirculation system}

As it was mentioned earlier two factors block the safety in case of emergency (in case of fire) in a system using recirculation such as goaf space in the underground part of the mining enterprise, which begins to play the role of a source of thrust during MVU reverse, and presence of isolating devices (AVD) in the main ventilation excavations in case of their failure. The same factors, but with less effect will affect the safety in the ventilation system without the partial air reuse.

In addition, presence AVD in the main ventilation excavations, which in case of failure can block the way for air supply to the working areas, makes their application dangerous also in the normal ventilation mode.

That is possible to increase the degree of safety while ensuring energy and resource saving of the ventilation and air conditioning process due to the recirculation system if the AVD are not located in the main ventilation excavations but in the excavations of the main directions (Fig. 2) [30].

In the normal mode the system will provide partial supply of the air coming from the pit (mine) back to a fresh sream. The volume flow of recirculated air will depend on the degree of its contamination (determined by the sensors of the air composition 10 in Fig. 2). Unlike the previously discussed ventilation system, the MVU performance will be regulated taking into account the effect of the mine general (shaft general) natural draft (thermal depression) arising between the shafts. As it was established in [31-34] using such a control method it is possible to reduce the ventilation costs from 11 to $32 \%$ (for potash mines). In this case, the AVD are in the open position and air distribution is controlled by the use of fans or insulating devices in the sections.

The mode of operation of the system and need to reverse the MVU are determined in advance, depending on the place of occurrence of fire during the period of the accident management. The information corresponding is stored in the memory of the programmable controller (PC), which will control the ventilation process.

The signal to close the AVD comes from the $\mathrm{PC}$ at the time when it is necessary to provide a reversible mode of ventilation in the mine (shaft). In order to prevent air impact the AVD are closed smoothly blocking the path of air movement into the goaf space through the air supplying trunks. A recirculation installation at that time continues to work. At the same time (in the reverse mode) fans of SAH switched off during the warm season are switched on or in the reversible mode are switched on in the cold season. Such the measures allow to change the direction of air movement in the air supply trunks and in the main directions (up to the AVD) to the desired direction (see Fig. 2).

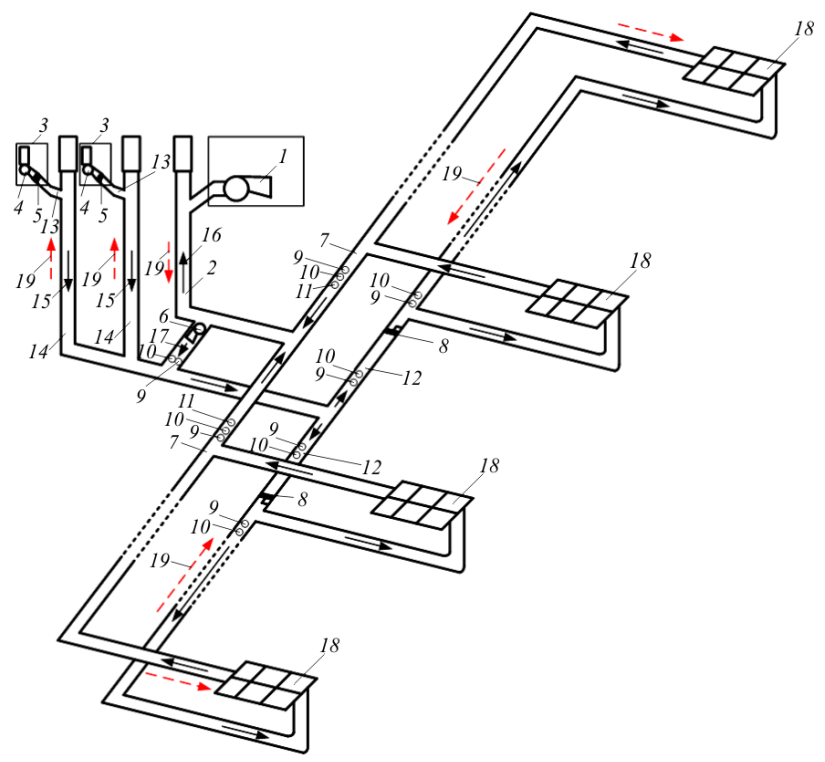

Fig. 2. Scheme of ventilation of the mine using the recirculation system according to the proposed method: 1 - MVU; 2 - ventilating trunk; 3 - building of the shaft air heater (SAH); 4 - fan SAH; 5 - heat exchanger SAH; 6 - recirculation fan; 7 - main ventilation excavations; 8 - automatic ventilation doors; 9 - air rate gauge; 10 - air composition sensors; 11 - pressure and temperature sensors (or densitometer); 12 - excavations of the main directions; 13 - heater channel; 14 - air supplying trunk; 15 - incoming air; 16 - discharged air; 17 - recirculation air; 18 - mining sites; 19 - required direction of air movement when the MVU is reversed

There are zones after the closure of AVD forms behind them, depression is occured which is acting counter to the direction of movement of air entering the goaf space and production sites. In this case, goaf space will be filled with air coming from the MVU side, i.e. air will move in the required direction, after which the recirculation unit is swithed off.

As soon as air supplying trunks and excavations of the main directions are provided with a reverse of the stream and AVD are opend. As a result there is 
a draft acting in the required direction, i.e. in the direction of air supplying trunks. The angle of opening is calculated in advance and determined by the signal level from the PC.

In this case, influence of the goaf spaces on the ventilation process during the reverse of the MVU will be minimized. As a result the air will start moving in the required direction in the mine (shaft) in the shortest possible time.

Safe working conditions for miners in case of using the method proposed, with the normal operation of the AVD and automation of recirculation will be provided both in normal and emergency operation modes of the mine ventilation system (pit). Energy saving during ventilation will be provided not only through the use of recirculation, but also in the process of regulating the operating mode of the MVU, taking into account the effect of a shaft general (mine shaft) natural draft.

\section{Operation of the ventilation system proposed in the event of equipment failures}

Due to the fact that AVD in the automation system of ventilation proposed in the normal mode are in the open position, they can not have any effect on the process of air distribution between the excavations. If that is assumed that, due to the failure of the AVD, they will close, this case will not threaten the miners when determining the next algorithm of system operation.

When the AVD is wedged in the closed position, air will continue to move in the required direction until the voids of the goaf space are completely filled. In order to increase the duration of the ventilation period in this mode, the MVU can be converted to a reduced productivity (considering the safety conditions for providing the mine with fresh air) and the recirculation unit must be shut down. As long as the air flow sensor in the recirculation loop does not show a change in the direction of air movement toward the air supply shafts, the MVU can operate in the established mode. The change (decrease in the speed of air movement to 0 ) of the direction of air movement in the recirculation circuit will indicate that all the air reserves contained in the goaf space have been delivered to the surface, i.e. indicate the situation when air in the ventilation trunk starts to flow from the air supply shafts bypassing the mining areas. In this case, the MVU and recirculation system have to be switched to the reverse mode, as a result of which fresh air will be directed to mine excavations.

The most likely situation represents the greatest danger will arise if the AVD are wedged in the closed position during the switching of the ventilation system to the reversible mode. In this case, the movement of fresh air towards the miner will be carried out until the goaf space is filled in from $40 \mathrm{~min}$ to $2 \mathrm{~h}[22,23]$. For that time interval the emergency situation (with AVD and / or fire) can be completely eliminated.

However, due to the fact the AVD in the proposed method is used only to create an aerodynamic resistance in the area of air intake from the air supplying trunks into the exhausted space, their design can be created in the way that closing parts of the door do not cover the entire mine excavations. In this case, the influence of the goaf space on the ventilation process will also be reduced, but conditions for safe mining will be fully provided in case of failure of the AVD.

\section{Conclusion}

The method of automation proposed will allow ventilating in energy and resource-saving modes at the expense of partial reuse of air (recycling) and positive effects of mine general (shaft general) natural draft considering the safety of mining.

The location of AVD in the excavations of the main directions will avoid the influence of goaf spaces on ventilation at the time of stream reversion. Wedging of AVD in the open position both in regular and emergency modes of ventilation will have practically no effect on the safety of work in the mine (shaft).

The only threat is the wedging of AVD in the closed position when reversing. In order to ensure the safety of working conditions with such a failure, it is sufficient to provide conditions for incomplete overlapping of AVD of the production section or create conditions under which such an accident will be eliminated during the filling of the goaf space with fresh air $(40 \mathrm{~min}-2 \mathrm{~h})$.

\section{References}

1. Starkov L.I., Zemskov A.N., Kondrashev P.I. Razvitie mekhanizirovannoi razrabotki kaliinykh rud [Development of mechanized development of potash ores]. Perm', Izdatel'stvo Permskogo gosudarstvennogo tekhnicheskogo universiteta, 2007, 522 p. 
2. Mokhirev N.N. Ispol'zovanie retsirkuliatsii vozdukha pri provetrivanii kaliinykh rudnikov [Use of air recirculation in the ventilation of potash mines]. Izvestiia vuzov. Gornyi zhurnal, 1987, no.9, pp.47-51.

3. Fainburg G.Z., Fominykh V.I. O raschete provetrivaniia ventiliatsionnykh setei dobychnogo uchastka $\mathrm{v}$ rezhime retsirkuliatsii [On the calculation of the ventilation of the ventilation networks of the mining section in the mode of recirculation]. Razrabotka solianykh mestorozhdenii, Perm',1980, pp.60-64.

4. Krasnoshtein A.E., Fainburg G.Z. Raschet gazovoi dinamiki pri retsirkuliatsionnom provetrivanii dobychnogo uchastka [Calculation of gas dynamics during recirculation airing of a mining site]. Ventiliatsiia shakht $i$ rudnikov, Leningrad, 1978, iss.5, pp.26-32.

5. Aldred R., Sproston J.H., Pearce R.J. Airconditioning and recirculation of mine air in North Nottinghamshire. Mining Engineer, 1984, vol.143, no.273, pp.601-607.

6. Lawton B.R. Local cooling underground by recirculation. Transaction of the Inst. Of Mining Engineers, 1933, vol. 90, pp.63-68.

7. Morris I.N., Walker G. Changes in the approach to ventilation in recent years. The Mining Eng, 1982, vol.141, no.244, pp.401-413.

8. Robinson R., Harrison T. Controlled recirculation of air at wearmouth colliery British coal corporation. Journal of Mine Ventilation Society South Africa, 1988, no.6, pp.78-87.

9. Robinson R., Harrison T. Controlled recirculation of air at Wearmouth Colliery. Mining Engineering, 1987, vol. 146, no.308, pp.661-671.

10. Vutukuri V.S., Lama R.D. How to maximize the recirculation of used air. Tunnel and Tunneling, 1988, no. 10, pp.57-59.

11. Bichall J. British start to recirculate air underground. Coal Age, 1987, vol.92, no.6, pp.44-45.

12. Nikolaev A.V., Fainburg G.Z. On energy and resource-saving of underground oil mine workings. Bulletin of Perm National Research Polytechnic University. Geology. Oil \& Gas Engineering \& Mining, 2015, no.14, pp.92-98. DOI: $10.15593 / 2224-9923 / 2015.14 .10$

13. Nikolaev A.V., Alymenko N.I. Primenenie sistemy konditsionirovaniia vozdukha $\mathrm{s}$ uchetom teplovykh depressii, deistvuiushchikh mezhdu stvolami [Application of the air conditioning system taking into account thermal depressions acting between the trunks]. Gornoe oborudovanie $i$ elektromekhanika, 2011, no.12, pp.12-15.

14. Zaitsev A.V., Kliukin Iu.A., Kiriakov A.S. Research in the process of heat and mass exchange in mine openings using the systems of partial air reuse. Bulletin of Perm National Research Polytechnic University. Geology. Oil \& Gas Engineering \& Mining, 2014, no.11, pp.121129. DOI: $10.15593 / 2224-9923 / 2014.11 .12$

15. Kruglov Iu.V. Teoreticheskie i tekhnologicheskie osnovy postroeniia sistem optimal'nogo upravleniia provetrivaniem podzemnykh rudnikov [Theoretical and technological foundations for constructing optimal control systems for ventilating underground mines]. Doctor's degree dissertation. Perm', 2012, 340 p.

16. Levin L.Iu., Kruglov Iu.V. Issledovanie retsirkuliatsionnogo sposoba provetrivaniia kaliinykh rudnikov i ego ekonomicheskaia effektivnost' [Investigation of the recycling method for the ventilation of potash mines and its economic efficiency]. Gornyi informatsionnoanaliticheskii biulleten', 2008, no.10, pp.39-48.

17. Golovatyi I.I., Kruglov Iu.V., Levin L.Iu. Shakhtnaia ventiliatornaia ustanovka $\mathrm{s}$ sistemoi avtomaticheskogo upravleniia dlia retsirkuliatsionnogo provetrivaniia kaliinykh rudnikov [Mine fan installation with automatic control system for recirculation airing of potash mines]. Gornyi zhurnal, 2010, no.8, pp.78-80.

18. Kruglov Iu.V., Levin L.Iu. Osnovy postroeniia optimal'nykh sistem avtomaticheskogo upravleniia provetrivaniem podzemnykh rudnikov [Basics of constructing optimal automatic control systems for ventilation of underground mines]. Izvestiia Tul'skogo gosudarstvennogo universiteta. Nauki o Zemle, 2010, iss.2, pp.104-109.

19. Mokhirev N.N. Razrabotka sovremennykh metodov i sredstv obespecheniia vysokoeffektivnogo provetrivaniia rudnikov, obladaiushchikh malymi aerodinamicheskimi soprotivleniiami [Development of modern methods and means to ensure highly effective ventilation of mines with low aerodynamic drags]. Doctor's degree dissertation. Perm', 1994, 302 p.

20. Krasnoshtein A.E., Fainburg G.Z. Upravlenie provetrivaniem shakht i rudnikov na osnove matematicheskogo modelirovaniia ventiliatsionnykh protsessov [Control of ventilation of mines and mines on the basis of mathematical modeling of ventilation processes]. Primenenie EVM i matematicheskikh metodov $v$ gornom dele. Trudy 17 mezhdunarodnogo simpoziuma. Moscow, 1982, vol.3, pp.10-12.

21. Pravila bezopasnosti pri vedenii gornykh rabot $i$ pererabotke tverdykh poleznykh iskopaemykh [Safety rules for mining and processing of solid minerals]. Federal'nye normy $\mathrm{i}$ pravila $\mathrm{v}$ oblasti promyshlennoi bezopasnosti. Moscow, Nauchno-tekhnicheskii tsentr issledovanii problem promyshlennoi bezopasnosti, 2014, seriia 03 , iss. $78,276 \mathrm{p}$.

22. Mokhirev N.N., Rad'ko V.V. Inzhenernye raschety ventiliatsii shakht. Stroitel'stvo. Rekonstruktsiia. Ekspluatatsiia [Engineering calculations of mine ventilation. Building. Reconstruction. Exploitation]. Moscow, Nedra-Biznestsentr, 2007, 324 p.

23. Postnikova M.Iu. Vliianie vyrabotannykh prostranstv na aerogazodinamicheskie protsessy pri avariinykh rezhimakh ventiliatsii rudnikov [Influence of the developed spaces on aerogasdynamic processes in emergency modes of mine ventilation]. Ph. D. thesis. Tula, 2010, $191 \mathrm{p}$.

24. Osipov S.N., Zhadan V.M. Ventiliatsiia shakht pri podzemnykh pozharakh [Ventilation of mines in underground fires]. Moscow, Nedra, 1973, $152 \mathrm{p}$.

25. Griffin R. In-mine evaluation of underground fire and smoke detectors. Morgantown WV, University of West Virginia, 1978, 18 p. 
26. Osipov S.N., Zhadan V.M. Dinamika pozhara v gorizontal'noi gornoi vyrabotke [Dynamics of fire in horizontal mining]. Ugol' Ukrainy, 1967, no.9, pp.15-17.

27. Hardcastle S.G., Kolada R.J., Stokes A.W. Studies into the wider application of controlled recirculation in Mine Ventilation. The mining Engineering (Gr. Brit.), 1984, vol.143, no.273, pp.591-598.

28. Wallace K.G., McPherson M.J., Brunner D.J., Kissel F.N. Impact of using auxiliary fans on coal mine ventilation efficiency and cost. Bur. mines US Dep. Inter., 1990, no.9307, pp.1-8.

29. Nikolaev A.V., Alymenko N.I., Nikolaev V.A. Meropriiatiia, prednaznachennye dlia zashchity gornorabochikh ot otravleniia ugarnym gazom $\mathrm{v}$ sluchae vozniknoveniia pozhara $\mathrm{v}$ konveiernom shtreke bloka kaliinogo rudnika [Measures designed to protect miners from carbon monoxide poisoning in the event of a fire in the conveyor drift of a block of potash mine]. Rudnik budushchego, 2012, no.2, pp.67-70.

30. Nikolaev A.V., Alymenko N.I., Nikolaev V.A., Alymenko D.N., Fainburg G.Z., Vavulin A.V. Sistema avtomatizatsii glavnoi ventiliatornoi ustanovki [The automation system of the main fan installation]: zaiavka na patent no.2017109327.
31. Nikolaev A.V. Upravlenie teplovymi depressiiami $\mathrm{v}$ sistemakh ventiliatsii kaliinykh rudnikov [Management of thermal depressions in potash mine ventilation systems]. Abstract of Ph. D. Thesis. Perm', 2012, 20 p.

32. Mokhirev N.N., Rad'ko V.V., Popov A.S. Vspomogatel'nye ventiliatornye ustanovki ezhektiruiushchego tipa [Auxiliary fan installations of ejection type]. Tekhnologiia vedeniia gornykh rabot $i$ proizvodstvo mashin dlia gornodobyvaiushchikh predpriiatii. Sbornik trudov. Perm', 2007, iss.3, pp.153-159.

33. Alymenko D.N. Rabota ventiliatornoi ustanovki kombinirovannogo tipa $\mathrm{v}$ rudnichnoi ventiliatsionnoi seti [The operation of a combined-type fan plant in a mine ventilation system]. Ph. D. thesis. Perm', 1999, $159 \mathrm{p}$.

34. Alymenko N.I., Nikolaev A.V., Nikolaev V.A. Ispol'zovanie teplovykh depressii i izoliruiushchikh ustroistv $\mathrm{s}$ tsel'iu povysheniia energoeffektivnosti provetrivaniia blokov kaliinykh rudnikov [The use of thermal depressions and insulating devices to improve the energy efficiency of ventilation blocks of potash mines]. Rudnik budushchego, 2012, no.3(11), pp.128-131.

\section{Библиографический список}

1. Старков Л.И., Земсков А.Н., Кондрашев П.И. Развитие механизированной разработки калийных руд. Пермь: Изд-во Перм. гос. техн. ун-та, 2007. - 522 с.

2. Мохирев Н.Н. Использование рециркуляции воздуха при проветривании калийных рудников // Известия вузов. Горный журнал. - 1987. - № 9. - С. 47-51.

3. Файнбург Г.3., Фоминых В.И. О расчете проветривания вентиляционных сетей добычного участка в режиме рециркуляции // Разработка соляных месторождений. - Пермь, 1980. - С. 60-64.

4. Красноштейн А.Е., Файнбург Г.3. Расчет газовой динамики при рециркуляционном проветривании добычного участка // Вентиляция шахт и рудников. - Л., 1978. - Вып. 5. - C. 26-32.

5. Aldred R., Sproston J.H., Pearce R.J. Airconditioning and recirculation of mine air in North Nottinghamshire // Mining Engineer. - 1984. - Vol. 143, № 273. - P. 601-607.

6. Lawton B.R. Local cooling underground by recirculation // Transaction of the Inst. Of Mining Engineers. - 1933. - Vol. 90. - P. 63-68.

7. Morris I.N., Walker G. Changes in the approach to ventilation in recent years // The Mining Eng. - 1982. Vol. 141, № 244. - P. 401-413.

8. Robinson R., Harrison T. Controlled recirculation of air at wearmouth colliery British coal corporation // Journal of Mine Ventilation Society South Africa. - 1988. - № 6. - P. 78-87.

9. Robinson R., Harrison T. Controlled recirculation of air at Wearmouth Colliery // Mining Engineering. 1987. - Vol. 146, № 308. - P. 661-671.

10. Vutukuri V.S., Lama R.D. How to maximize the recirculation of used air // Tunnel and Tunneling. - 1988. № 10. - P. 57-59.
11. Bichall J. British start to recirculate air underground // Coal Age. - 1987. - Vol. 92, № 6. - P. 44- 45.

12. Николаев А.В., Файнбург Г.З. Об энерго- и ресурсосберегающем проветривании подземных горных выработок нефтешахт // Вестник Пермского национального исследовательского политехнического университета. Геология. Нефтегазовое и горное дело. - 2015. № 14. - C. 92-98. DOI: 10.15593/2224-9923/2015.14.10

13. Николаев А.В., Алыменко Н.И. Применение системы кондиционирования воздуха с учетом тепловых депрессий, действующих между стволами // Горное оборудование и электромеханика. - 2011. - № 12. - С. 12-15.

14. Зайцев А.В., Клюкин Ю.А., Киряков А.С. Исследование процессов тепломассопереноса в горных выработках при применении систем частичного повторного использования воздуха // Вестник Пермского национального исследовательского политехнического университета. Геология. Нефтегазовое и горное дело. - 2014. - № 11. C. 121-129. DOI: 10.15593/2224-9923/2014.11.12

15. Круглов Ю.В. Теоретические и технологические основы построения систем оптимального управления проветриванием подземных рудников: дис. ... д-ра техн. наук. - Пермь, 2012. - 340 с.

16. Левин Л.Ю., Круглов Ю.В. Исследование рециркуляционного способа проветривания калийных рудников и его экономическая эффективность // Горный информационно-аналитический бюллетень. 2008. - № 10. - С. 39-48.

17. Головатый И.И., Круглов Ю.В., Левин Л.Ю. Шахтная вентиляторная установка с системой автоматического управления для рециркуляционного проветривания калийных рудников // Горный журнал. 2010. - № 8. - С. 78-80. 
18. Круглов Ю.В., Левин Л.Ю. Основы построения оптимальных систем автоматического управления проветриванием подземных рудников // Известия Тульского государственного университета. Науки о Земле. - 2010. - Вып. 2. - С. 104-109.

19. Мохирев Н.Н. Разработка современных методов и средств обеспечения высокоэффективного проветривания рудников, обладающих малыми аэродинамическими сопротивлениями: дис. ... д-ра техн. наук / Перм. гос. техн. ун-т. - Пермь, 1994. - 302 с.

20. Красноштейн А.Е., Файнбург Г.3. Управление проветриванием шахт и рудников на основе математического моделирования вентиляционных процессов // Применение ЭВМ и математических методов в горном деле: тр. 17-го междунар. симп. M., 1982. - T. 3. - C. 10-12.

21. Правила безопасности при ведении горных работ и переработке твердых полезных ископаемых: Федеральные нормы и правила в области промышленной безопасности. - М.: Научно-технический центр исследований проблем промышленной безопасности, 2014. - Cер. 03, вып. 78. - 276 с.

22. Мохирев Н.Н., Радько В.В. Инженерные расчеты вентиляции шахт. Строительство. Реконструкция. Эксплуатация. - М.: Недра-Бизнесцентр, 2007. - 324 с.

23. Постникова М.Ю. Влияние выработанных пространств на аэрогазодинамические процессы при аварийных режимах вентиляции рудников: дис. ... канд. техн. наук. - Тула, 2010. - 191 с.

24. Осипов С.Н., Жадан В.М. Вентиляция шахт при подземных пожарах. - М.: Недра, 1973. - 152 с.

25. Griffin R. In-mine evaluation of underground fire and smoke detectors. - Morgantown WV: University of West Virginia, 1978. - 18 p.

26. Осипов С.Н., Жадан В.М. Динамика пожара в горизонтальной горной выработке // Уголь Украины. 1967. - № 9. - С. 15-17.
27. Hardcastle S.G., Kolada R.J., Stokes A.W. Studies into the wider application of controlled recirculation in Mine Ventilation // The mining Engineering (Gr. Brit.). 1984. - Vol. 143, № 273. - P. 591-598.

28. Impact of using auxiliary fans on coal mine ventilation efficiency and cost / K.G. Wallace, M.J. McPherson, D.J. Brunner, F.N. Kissel // Bur. mines US Dep. Inter. - 1990. - № 9307. - P. 1-8.

29. Николаев А.В., Алыменко Н.И., Николаев В.А. Мероприятия, предназначенные для защиты горнорабочих от отравления угарным газом в случае возникновения пожара в конвейерном штреке блока калийного рудника // Рудник будущего. - 2012. № 2. - C. 67-70.

30. Система автоматизации главной вентиляторной установки: заявка на патент № 2017109327 / Николаев А.В., Алыменко Н.И., Николаев В.А., Алыменко Д.Н., Файнбург Г.3., Вавулин А. В.; заявл. 20.03.2017.

31. Николаев А.В. Управление тепловыми депрессиями в системах вентиляции калийных рудников: автореф. дис. ... канд. техн. наук / Перм. нац. исслед. политех. ун-т. - Пермь, 2012. - 20 с.

32. Мохирев Н.Н., Радько В.В., Попов А.С. Вспомогательные вентиляторные установки эжектирующего типа // Технология ведения горных работ и производство машин для горнодобывающих предприятий: сб. тр. - Пермь, 2007. - Вып. 3. С. $153-159$.

33. Алыменко Д.Н. Работа вентиляторной установки комбинированного типа в рудничной вентиляционной сети: дис. ... канд. техн. наук / Горный институт УрО РАН. - Пермь, 1999. - 159 с.

34. Алыменко Н.И., Николаев А.В., Николаев В.А. Использование тепловых депрессий и изолирующих устройств с целью повышения энергоэффективности проветривания блоков калийных рудников // Рудник будущего. - 2012. - № 3(11). - С. 128-131.

Please cite this article in English as:

Nikolaev A.V., Alymenko N.I., Chekhlar M., Janocko Yu., Alymenko D.N., Nikolaev V.A. Ensuring the safety and energy efficiency of ventilation of shafts and mines that use the air recycling system. Perm Journal of Petroleum and Mining Engineering, 2017, vol.16, no.4, pp.370-377. DOI: 10.15593/2224-9923/2017.4.8

Просьба ссылаться на эту статью в русскоязычных источниках следующим образом:

Обеспечение безопасности и энергоэффективности при проветривании шахт и рудников, использующих систему рециркуляции воздуха / А.В. Николаев, Н.И. Алыменко, М. Чехлар, Ю. Яночко, Д.Н. Алыменко, В.А. Николаев // Вестник Пермского национального исследовательского политехнического университета. Геология. Нефтегазовое и горное дело. 2017. - T.16, №4. - C.370-377. DOI: 10.15593/2224-9923/2017.4.8 